UDK $630 * 165.5+630 * 232.12: 582.475$

Original scientific paper

\title{
VARIABILITY OF RESIN CANAL DIAMETER IN THE NEEDLES OF DIFFERENT DOUGLAS-FIR PROVENANCES
}

\author{
Vera LAVADINOVIĆl , Dragica OBRATOV-PETKOVIĆ ${ }^{2}$ Ljubinko RAKONJAC ${ }^{l}$, \\ Zoran MILETIĆ ${ }^{l}$, Filip JOVANOVIĆ ${ }^{l}$, Milan KABILJO ${ }^{l}$
}

\begin{abstract}
Douglas-fir is the most commonly grown allochthonous species in the forests of Europe. Growth speed, adaptive power, favorable wood properties, as well as low sensibility to pests are the attributes that have contributed the most to the success and occurrence of Douglas-fir plantations in Europe. Introduction program of an exotic species includes testing of its provenances in new ecosystems and localities. In Serbia, testing of the genetic potentials of Douglas-fir, native to North America, has begun by seting up provenance trials on several locations. Afforestation with exotic tree species must be justified and it should fulfill the aims of the introduction. Therefore, it is neccessary to test all the traits of the introduced species to show the effects of ecological factors. The aim of this research was to determine the ecological adaptations of Douglas-fir in Serbia by studying its anatomic characteristics. In the paper, the influence of locality conditions on the diameter of resin canals in the needles of different Douglas-fir provenances was investigated on the sites where the provenance tests were set up. A two-way ANOVA was performed, by investigating the effects of site and provenance factors on the diameter of resin canals. Resin canals serve as an important diagnostic taxonomic characteristic in conifers, while resin itself has important physiological and protective role in conifers.
\end{abstract}

\footnotetext{
${ }^{1}$ Dr Vera Lavadinović, Dr Ljubinko Rakonjac, Dr Zoran Miletić, Dr Filip Jovanović, MSc Milan Kabiljo, Institute of Forestry, 3 Kneza Višeslava, 11030 Belgrade, Serbia.

${ }^{2}$ Dr Dragica Obratov-Petković, Faculty of Forestry, University of Belgrade, 1 Kneza Višeslava, 11030 Belgrade, Serbia.

Author for correspondence: Dr Vera Lavadinović, Institute of Forestry, 3 Kneza Višeslava, 11030 Belgrade, Serbia, +381628838010, e-mail: veralava@ outlook.com

* Acknowledgments: The paper was realized as a part of projects "Studying climate change and its influence on the environment: impacts, adaptation and mitigation" (43007) and "The development of technological processes in forestry in order to realize the optimal forest cover" (31070), financed by the Ministry of Education, Science and Tecnological Development of the Republic of Serbia within the framework of integrated and interdisciplinary research for the period 2011-2019.
} 
Key words: Douglas-fir, provenance, introduction, resin canals, Serbia

\section{VARIJABILNOST PREČNIKA SMOLNIH KANALA U ČETINAMA RAZLIČITIH PROVENIJENCIJA DUGLAZIJE}

Izvod: U šumama Evrope najzastupljenija introdukovana vrsta četinara je duglazija. Veliki kapacitet produktivnosti i adaptivnosti, kao i kvalitet drveta i mali broj štetočina, prednosti su koje su doprinele da se ova vrsta uspešno primenjuje u šumskim kulturama Evrope. Program introdukcije egzotične vrste podrazumeva testiranje njenih različitih provenijencija u novim ekosistemima i lokalitetima. U Srbiji, program testiranja genetskog potencijala duglazije, poreklom iz Severne Amerike, započet je osnivanjem provenijeničnih testova na više lokacija. Koncept pošumljavanja sa egzotičnim vrstama drveća mora biti opravdan i da ispuni cilj introdukcije. Iz tog razloga, potrebno je testirati sve karakteristike introdukovane vrste, koje će prikazati uticaj ekoloških faktora. Cilj ovog istraživanja je da se utvrde ekološke adaptacije duglazije u Srbiji proučavanjem njenih anatomskih karakteristika. U radu su istraživani efekti stanišnih uslova lokaliteta, gde su osnovani provenijenični testovi duglazije u Srbiji, na prečnik smolnih kanala u četinama duglazije različitih provenijencija. Obavljena je dvofaktorijalna analiza varijanse, ispitivani su faktori lokaliteta $i$ provenijencija, kao i njihov uticaj na prečnik smolnih kanala. Smolni kanali su važna taksonomska karakteristika četinara, dok sadržaj smole ima važnu fiziološku i zaštitnu ulogu u njima.

Ključne reči: duglazija, provenijencije, introdukcija, smolni kanali, Srbija

\section{INTRODUCTION}

Douglas-fir [Pseudotsuga menziesii (Mirb.) Franco, fam. Pinaceae] occurs in all ecosystems of Europe, providing with fast and high-quality wood production, landscape diversity, as well as lucrative materials for medicinal and industrial use. Its natural range of distribution is in the northern part of Canada and the Pacific coast, up to 3,000 m a. s. 1. on Rocky Mts. Its wide geographical range in terms of latitude, longitude (from New Mexico to Vancouver) and altitude has produced a number of provenances.

In the publication "Douglas-fir - an option for Europe" (Spiecker et al., 2019), the authors emphasise the fact that this species has highly adaptive genetic variability, and it is very suitable for introduction. The first seeds were introduced in Europe by David Douglas in 1827 and then planted at Dropmore Park (Buckinghamshire, UK), where there is a tree which is usually considered the oldest Douglas-fir of Europe (Da Ronch et al., 2016; Elwes and Henry, 1969).

Douglas-fir is an up-and-coming, highly productive introduced species, not only in Europe but also in the world; hence, it was a subject of numerous studies and a topic of many scientific conferences (Chen et al., 1986; Hermann and Lavender, 1987, 1990).

In Serbia, the study and the testing of Douglas-fir provenances from Canada and the United States of America has begun in 1978 at the Institute of Forestry, Belgrade, by setting up provenance trials on different sites (Lavadinović 
and Koprivica, 1996, 1996a, 1999, 2000; Lavadinović and Isajev, 2005; Lavadinović, 2005; Lavadinović et al., 2010, 2011, 2015, 2017, 2018).

Resin canals are a common, distinguishing feature in conifers (Fahn, 1979; Page, 1989). Resin canals are relatively large intercellular spaces surrounded by an epithelium of secretory parenchyma cells (Fahn, 1979) that occur in many organs of coniferophytes. In Pinaceae, they are found in xylem, bark, needles and seeds (Lin et al., 1995; Farjon, 1998; Wu and Hu, 1997). In addition to pines, a number of other conifer species, including Douglas-fir, exhibit resin canals in their needles. Apart from the needles, the resin ducts are distributed in the cortex, primary xylem and secondary xylem of stems. In the needles, two lateral, abaxial ducts occur in the mesophyll ( $\mathrm{Wu}$ and $\mathrm{Hu}, 1997$ ). The two adaxial resin ducts of Pseudotsuga menziesii needles are located in direct contact with epidermis. They present a central midvein with variable diameter, surrounded by a thin endodermis. Each canal is sometimes partially surrounded by sclerenchyma fibers with lignified walls (Pădure et al., 2008).

Resin canals exude a complex of secondary metabolites (resin or pitch) as a result of injury from wind, fire or attack by wood-boring insects. There are many commercial purposes for resin, including lacquers, varnishes and turpentine (Kramer and Kozlowski, 1979). The resin itself is an organic liquid containing terpenes, resin acids and other compounds. Needle resin serves as defense against insects and other animals, which confront the distasteful substance when boring into the conifer's leaves. Resin is antiseptic and aromatic and prevents the development of fungi and deters insects. The resins may disrupt the feeding, digestion or metabolic function of the attacker (https://www.hunker.com).

Resin canals also serve as an important diagnostic taxonomic characteristic in conifers (Lin et al., 2000; Frankis, 1989). Specifically, the crosssectional number of resin canals in conifer needles can be used to distinguish genetic variation among families and subspecies (Helmers, 1943; Keng and Little, 1962) and is thus commonly used as an index in forest breeding programs (Richardson, 1998., Lin et al., 2001).

The aim of this research was to determine the ecological adaptations of Douglas-fir in Serbia by studying its anatomic characteristics. The influence of locality conditions on the diameter of resin canals in the needles of different Douglas-fir provenances was investigated on the sites where the provenance tests were set up.

\section{MATERIAL AND METHODS}

Provenance trial plantations in Serbia were established as a starting material for the provenance tests. The experimental plots on Mt. Juhor (near the city of Jagodina) and Tanda (near Bor) were set in order to begin with the testing program of introduced species.

The plantations were established using seedlings produced in the nursery of the Institute of Forestry, Belgrade. The seedlings were raised from seed which has been collected in one part of the native range of Douglas-fir's distribution in North America. The origin of the provenances is shown in Table 1. 
The experiment on Mt. Juhor was set on the site of mountain beech forest (Fagetum moesiacae montanum Jov. 1976) on acid brown soil (dystric cambisol) over gneiss. The "Tanda" sample plot is located in FMU "Stol" (FAS "Bor") on the site of Hungarian and Turkey oak forest (Quercetum frainetto-cerris Rud. 1949) on acid brown soil and sierozem (Lavadinović, 2009).

Table 1. Geographical coordinates of the tested Douglas-fir provenances

\begin{tabular}{||l|c||c|c|c||}
\hline Provenance code & Mark & $\begin{array}{c}\text { Catitude } \\
\left({ }^{(\mathbf{N})}\right.\end{array}$ & $\begin{array}{c}\text { Congitude } \\
\left({ }^{\mathbf{} E}\right)\end{array}$ & $\begin{array}{c}\text { Altitude } \\
(\mathbf{m})\end{array}$ \\
\hline \hline Oregon 205-15 & 1 & 43.7 & 123.0 & 750 \\
\hline Oregon 205-14 & 2 & 43.8 & 122.5 & 1200 \\
\hline Oregon 202-27 & 3 & 45.0 & 122.4 & 450 \\
\hline Oregon 205-38 & 4 & 45.0 & 121.0 & 600 \\
\hline \hline Washington 204-07 & 9 & 49.0 & 119.0 & 1200 \\
\hline Oregon 205-13 & 10 & 43.8 & 122.5 & 1050 \\
\hline Oregon 205-18 & 11 & 44.2 & 122.2 & 600 \\
\hline Oregon 202-22 & 12 & 42.5 & 122.5 & 1200 \\
\hline Washington 202-17 & 15 & 47.6 & 121.7 & 600 \\
\hline Oregon 201-10 & 16 & 44.5 & 119.0 & 1350 \\
\hline Washington 201-06 & 17 & 49.0 & 120.0 & 750 \\
\hline \hline Oregon 202-19 & 18 & 45.3 & 123.8 & 300 \\
\hline Oregon 205-11 & 20 & 45.0 & 123.0 & 150 \\
\hline New Mexico 202-04 & 22 & 32.9 & 105.7 & 2682 \\
\hline New Mexico 202-10 & 23 & 36.0 & 106.0 & 2667 \\
\hline Oregon 202-31 & 24 & 44.3 & 118.8 & 1500 \\
\hline Oregon 205-29 & 26 & 42.6 & 122.8 & 900 \\
\hline Oregon 205-08 & 27 & 42.7 & 122.5 & 1050 \\
\hline \hline Oregon 204-04 & 30 & 45.0 & 121.5 & 300 \\
\hline \hline Washington 205-17 & 31 & 47.7 & 123.0 & 300 \\
\hline Source: Lavadinović and Koprivica $(1996)$ & \\
\hline
\end{tabular}

For the purposes of the analysis of site influence on the variability of anatomical structure of Douglas-fir needles collected on both sites where the provenance tests were set, samples were taken only from selected provenances. The selection of provenances was based on previous research of the variability of mensurational parameters in Douglas-fir (Lavadinović, 2009). In each locality three groups of provenances were formed: 1 - the best, 2 - medium and 3 - the worst. The paper analyzes two provenances from each category - the best (18 and 31 ), medium (16 and 17) and the worst (9 and 24).

Fresh needles were fixed in 50\% ethyl alcohol to make permanent anatomical cross-sections, which contained 30 randomly chosen needles. The median anatomical sections were cut to a thickness of $17 \mu \mathrm{m}$, using a microtome. After that, they were stained with Safranin red and Toluidine blue and washed with water. Ethyl-alcohol dehydration was then performed by increasing the concentration of alcohol from 50\% to $96 \%$. Post-fixation of the sections was performed with xylene, which required several hours to complete. Finally, the needles were glued to the cover glass using Canadian balsam, covered with the glass and dried in an oven at $60^{\circ} \mathrm{C}$ (Lavadinović et al., 2017). Morpho-anatomic features were measured three weeks later. Taking into account the sample sizes of 
the groups being compared, all the obtained numerical data were analyzed using the two-way ANOVA and LSD test.

\section{RESULTS AND DISCUSSION}

The results of the two-way analysis of variance (site $\mathrm{x}$ provenance) for the property diameter of the needle resin canals of Douglas-fir are given in Table 2. Based on the results presented, it can be concluded that there are:

a) statistically significant differences between the mean values of resin canal diameters in the needles collected on Mt. Juhor and Tanda sites;

b) statistically significant differences between the mean values of resin canal diameters in the needles of some provenances analyzed;

c) significant influence of the interaction of "site" and "provenance" factors on the mean values of resin canal diameters.

Table 2. A two-way analysis of variance (site x provenance) for the property diameter of the needle resin canals of Douglas-fir

\begin{tabular}{|l||c||c|c|c||c||}
\hline $\begin{array}{c}\text { Source of } \\
\text { variation }\end{array}$ & $\begin{array}{c}\text { Sum of } \\
\text { squares }\end{array}$ & $\begin{array}{c}\text { The degree } \\
\text { of freedom }\end{array}$ & Variance & F-ratio & $\boldsymbol{p}$-value \\
\hline \hline A: Site & 13634.6 & 1 & 13634.6 & 87.16 & 0.000 \\
\hline B: Provenance & 52465.9 & 5 & 10493.2 & 67.08 & 0.000 \\
\hline \hline Interaction AB & 42525.4 & 5 & 8505.08 & 54.37 & 0.000 \\
\hline \hline Errors & 54435.8 & 348 & 156.425 & & \\
\hline \hline Total & 163062.0 & 359 & & & \\
\hline
\end{tabular}

\subsection{The effect of site on the diameter of resin canals}

Based on to the results presented in Table 3, it can be concluded that there are statistically significant differences between the mean values of resin canal diameters of the needles collected on Mt. Juhor and Tanda. The mean resin canal diameter determined for the provenances at Tanda site $(91.1 \mu \mathrm{m})$ is significantly greater than that determined for the needles collected on Mt. Juhor $(78.79 \mu \mathrm{m})$. In addition, variability of the resin canal diameters of the analyzed provenances was detected on both sites, as shown in Graphs 1 and 2.

Table 3. An LSD test of site influence on the diameter of resin canals

\begin{tabular}{||c||c||c||c|c||}
\hline \hline Site & $\begin{array}{c}\text { Sample } \\
\text { size }\end{array}$ & $\begin{array}{c}\text { Mean } \\
\text { values }\end{array}$ & $\begin{array}{c}\text { Standard error of the difference } \\
\text { between the means }\end{array}$ & $\begin{array}{c}\text { Homogeneous } \\
\text { groups }\end{array}$ \\
\hline \hline Juhor & 180 & 78.79 & 0.932216 & $X$ \\
\hline \hline Tanda & 180 & 91.1 & 0.932216 & $\mathrm{X}$ \\
\hline \hline Comparison & & Differences & $+/$ Limit \\
\hline \hline Juhor-Tanda & $*-12.3083$ & 2.59295 \\
\hline
\end{tabular}

*statistically significant difference

\subsection{The effect of provenance on the diameter of resin canals}

The LSD test was used to determine whether there is a relation between the genefond of the introduced provenances and the variability of resin canal diameter in the needles of Douglas-fir. The results are presented in Table 4. 
The results presented in Table 4 indicate that there are statistically significant differences between the resin canal diameters of Douglas-fir; however, the results of the LSD test show that some of the provenances analyzed $(31,18,24$, 16,9 and 17) were homogeneous, i.e. the mean values of the resin canal diameters were not statistically significant for the same provenances.

Table 4. An LSD test of provenance influence on the diameter of resin canals

\begin{tabular}{|c||c||c||c|c||}
\hline \hline Provenance & Sample size & $\begin{array}{c}\text { Mean } \\
\text { values }\end{array}$ & $\begin{array}{c}\text { Standard error of the difference } \\
\text { between the means }\end{array}$ & $\begin{array}{c}\text { Homogeneous } \\
\text { groups }\end{array}$ \\
\hline \hline 31 & 60 & 67.250 & 1.61465 & $\mathrm{X}$ \\
\hline \hline 18 & 60 & 70.925 & 1.61465 & $\mathrm{X}$ \\
\hline \hline 24 & 60 & 85.875 & 1.61465 & $\mathrm{X}$ \\
\hline \hline 16 & 60 & 89.625 & 1.61465 & $\mathrm{X}$ \\
\hline \hline 9 & 60 & 97.250 & 1.61465 & $\mathrm{X}$ \\
\hline \hline Comparison & 60 & 98.750 & 1.61465 & $+/-$ Limit \\
\hline \hline $9-16$ & & Differences & 4.49111 \\
$9-17$ & & 7.625 & 4.4911 \\
$9-18$ & & -1.5 & 4.49111 \\
$9-24$ & & $* 26.325$ & 4.49111 \\
$9-31$ & & $* 11.375$ & 4.49111 \\
$16-17$ & & $* 30.0$ & 4.49111 \\
$16-18$ & & $*-9.125$ & 4.49111 \\
$16-24$ & & $* 18.7$ & 4.49111 \\
$16-31$ & & 3.75 & 4.49111 \\
$17-18$ & & $* 22.375$ & 4.49111 \\
$17-24$ & & $* 27.825$ & 4.49111 \\
$17-31$ & & $* 12.875$ & 4.49111 \\
$18-24$ & & $*-14.95$ & 4.49111 \\
$18-31$ & & 3.675 & 4.49111 \\
$24-31$ & & $* 18.625$ & \\
\hline
\end{tabular}

*statistically significant difference

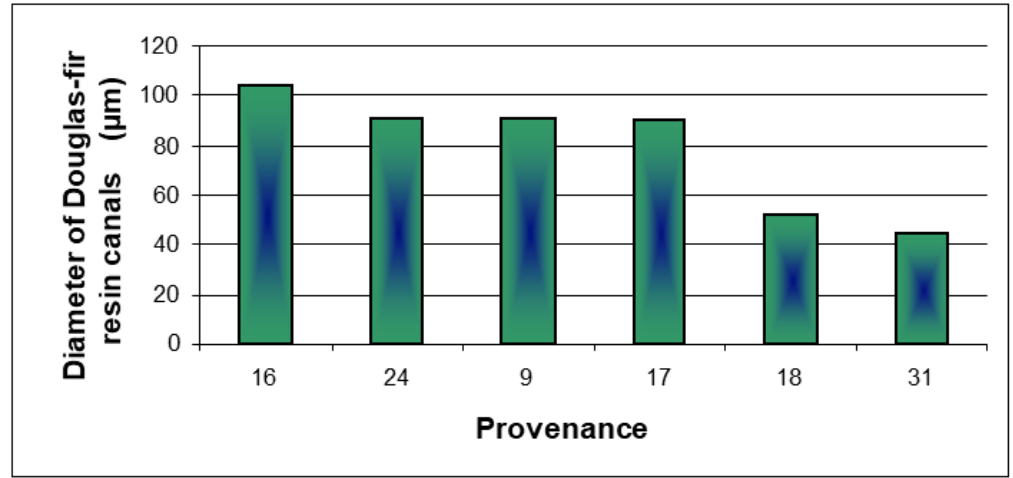

Graph 1. Variability of resin canal diameter between different provenances on Mt. Juhor 


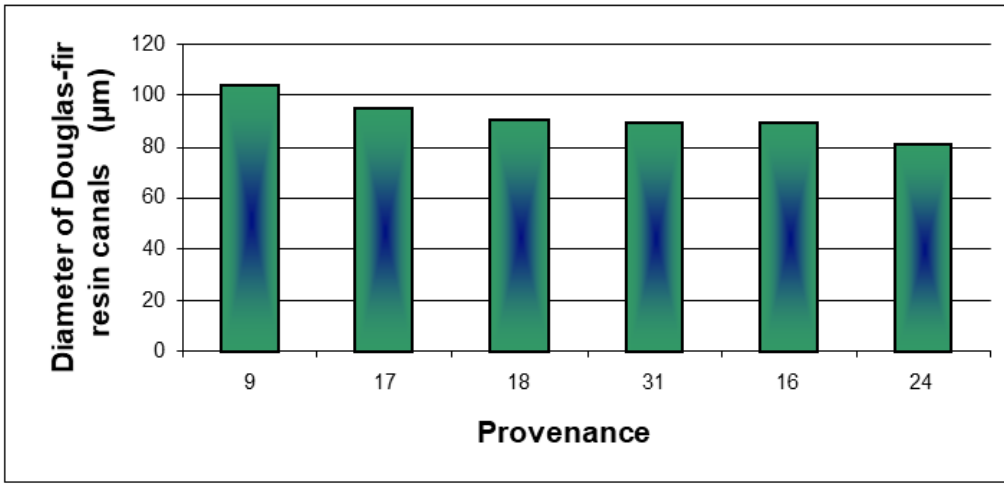

Graph 2. Variability of resin canal diameter between different provenances on Tanda site

The results are comparable with those published by Pădure et al. (2008). In the study of the relationships of Pseudotsuga menziesii populations in Romania, several anatomical characters were found to be significant, including resin duct diameters in the needles. Resin ducts varied in diameter from 31,25 to $68,70 \mu \mathrm{m}$ (Pădure et al., 2008). Therefore, it can be concluded that allmost all provenances analyzed in our study (except for 31) had greater average resin duct diameters than those presented in the literature.

\section{CONCLUSIONS}

Douglas-fir is an introduced conifer species that should take a significant place in the ecosystems of Serbia. As it comes from a wide natural range of distribution, the proper provenance selection is a necessary step in the confirmation of its genetic potentials in new ecological conditions. The genetic control of its anatomical and morphological traits could be tested by provenance trials. In the context of genetic improvement programmes of introduced tree species, Institute of Forestry, Belgrade, has assessed different Douglas-fir provenances in Serbia.

In the present study, the hypothesis that there are significant differences between the mean values of resin canal diameters of the needles of Douglas-fir on different experimental plots in Serbia has been confirmed. In some provenances, it was determined that there are significant differences between the mean values of resin canal diameters and that the interaction of "site" and "provenance" factors has significant influence on the mean values.

The results of this study will contibute to better selection of suitable provenances for the introduction of Douglas-fir in Serbia. In addition, the strategy of the introduction of exotic tree species will contribute to better afforestation programs and will provide high-quality raw materials for the wood industry.

\section{REFERENCES}

Chen, Z. Y., Scagel, R. K. and Maze, J. (1986): A study of morphological variation in Pseudotsuga menziesii in southwestern British Columbia, Can. J. Bot., 64: 1654-1663 
Da Ronch, F., Caudullo, G. and De Rigo, D. (2016): Pseudotsuga menziesii in Europe: distribution, habitat, usage and threats. In: San-Miguel-Ayanz J., De Rigo D., Caudullo G., Houston Durrant T. and Mauri A. (eds). European atlas of forest tree species. Publication Office of the European Union. Luxembourg. 146-147

Elwes, H. J. and Henry, A. (1969): The trees of Great Britain and Ireland. Volume 4. S. R. Publishers Ltd. East Ardsley

Fahn, A. (1979): Secretory tissues in plants. Academic Press. New York and London

Farjon, A. (1998): World checklist and bibliography of conifers. Royal Botanic Gardens Kew. Richmond

Frankis, M. P. (1989): Generic inter-relationships in Pinaceae, Notes R. Bot. Gard. Edinb., 45: $527-548$

Helmers, A. E. (1943): The ecological anatomy of Ponderosa pine needles, Am. Midl. Nat., 29: $55-71$

Hermann, R. and Lavender, D. (1987): North American tree species in Europe, Journal of Forestry, 85(12): 27-32

Herman, R. and Lavender, D. (1990): Pseudotsuga menziesii (Mirb.) Franco: Douglas-fir. In: Burns R. M. and Honkala B. H. (coords). Silvics of North America Volume 1. Conifers. USDA Forest Service. 527-540

Keng, H. and Little, E. L. (1962): Needle characteristics of hybrid pines, Silvae Genet., 11: $131-146$

Kramer, P. J. and Kozlowski, T. T. (1979): Physiology of woody plants. Academic Press. New York

Lavadinović, V. and Koprivica, M. (1996): Tracheid width of different Douglas-fir (Pseudotsuga taxifolia Britt.) provenances in test plantations in the region of Serbia. Second International Conference on the Development of Wood Science Technology and Forestry Proceedings. Sopron. 287-296

Lavadinović, V. and Koprivica, M. (1996a): Development of young Douglas-fir (Pseudotsuga taxifolia Britt.) stands of different provenances on beech sites in Serbia. IUFRO Conference "Modeling Regeneration Success and Early Growth of Forest stands" Proceedings. Copenhagen. 390-399

Lavadinović, V. and Koprivica, M. (1999): Development of young Douglas-fir stands of different provenances on oak site in Serbia. IUFRO Conference "Empirical and Processbased Models for Forest Tree and Stand Growth Simulation” Proceedings. Lisboa. 231-241

Lavadinović, V. and Koprivica, M. (2000): Douglas-fir provenance tests in Serbia. XXI IUFRO World Congress "Forest and Society: Role of Research" Poster abstracts 3. Kuala Lumpur. 81 
Lavadinović, V. and Isajev, V. (2005): Applicaton of introduction as a method of tree breeding - the example of Douglas-fir (Pseudotsuga menziesi /Mirb./ Franco). Transilvania University of Brasov - Faculty of Silviculture and Forest Engineering. Brasov

Lavadinović, V. (2009): Genetic and ecological components of the variability of Douglasfir (Pseudotsuga menziesii Mirb. Franco) in test plantations in Serbia. PhD Thesis. University of Belgrade - Faculty of Forestry. Belgrade (In original: Lavadinović, V. (2009): Genetske i ekološke komponente varijabilnosti duglazije (Pseudotsuga menziesii Mirb. Franco) u provenijeničnim testovima na području Srbije. Doktorska disertacija. Univerzitet u Beogradu - Šumarski fakultet. Beograd)

Lavadinović, V., Isajev, V., Rakonjac, Lj. and Lučić, A. (2010): Influence of ecological characteristics of Douglas-fir test plantations in Serbia on trees survival. International conference "People, Forests and the Environment coexisting in Harmony" Book of abstracts. Casablanca. 42

Lavadinović, V., Miletić, Z., Isajev, V. and Krstć, M. (2011): Variability of nitrogen content in the needles of Douglas-fir provenance (Pseudotsuga menziesii /Mirb./ Franco), Genetika, 43(2): 407-417

Lavadinović, V., Miletić, Z. and Lavadinović, V. (2015): Variability of nitrogen and carbon contents in the needles of Canadian Douglas-fir provenances on two soil types in Serbia, Baltic Forestry, 21(2/41): 272-278

Lavadinović, V., Rakonjac, Lj. and Lavadinović, V. (2017): Variability of epitelial cells in the duct of Douglas-fir needles, Sustainable Forestry, 75-76: 13-20

Lavadinović, V. S., Miletić, Z., Rakonjac, Lj. and Lavadinović, V. M. (2018): Magnesium concentration in the Canadian Douglas-fir needles of different provenances, Sustainable Forestry, 77-78: 45-55

Lin, J. X., Hu, Y. S. and Wang, F. H. (1995): Wood and bark anatomy of Nothotsuga (Pinaceae), Ann. Mo. Bot. Gard., 82: 603-609

Lin, J. X., Liang, E. Y. and Farjon, A. (2000): The occurrence of vertical resin canals in Keteleeria, with reference to its systematic position in Pinaceae, Bot. J. Linn. Soc., 134: 567-574

Lin, J. X., Sampson, D. A. and Ceulemans, R. (2001): The effect of crown position and tree age on resin-canal density in Scots Pine (Pinus sylvestris L.) needles, Can. J. Bot., 79: $1257-1261$

Pădure, I. M., Bădulescu, L., Dediu, T., Burzo, I. (2008): Morpho-anatomical and phytochemical researches regarding Pseudotsuga menziesii (Mirbel) Franco (Pinaceae), Analele ştiinţifice ale Universităţii “Al. I. Cuza” Iaşi Tomul, 54(1): 33-39

Page, C. N. (1989): New and maintained genera in the conifer families Podocarpaceae and Pinaceae, Notes R. Bot. Gard. Edinb., 45: 377-395

Richardson, D. M. (1998): Ecology and biogeography of Pinus. Cambridge University Press. Cambridge 
Spiecker, H., Lindner, M. and Schuler, J. (2019): Douglas-fir - an option for Europe. What Science Can Tell Us 9. European Forest Institute. Joensuu

Wu, H. and Hu, Z. H. (1997): Comparative anatomy of resin ducts of the Pinaceae, Trees, 11: $135-143$

\title{
VARIABILITY OF RESIN CANAL DIAMETER IN THE NEEDLES OF DIFFERENT DOUGLAS-FIR PROVENANCES
}

\author{
Vera LAVADINOVIĆ, Dragica OBRATOV-PETKOVIĆ, Ljubinko RAKONJAC, \\ Zoran MILETIĆ, Filip JOVANOVIĆ, Milan KABILJO
}

\section{Summary}

Douglas-fir [Pseudotsuga menziesii (Mirb.) Franco, fam. Pinaceae] occurs in all ecosystems of Europe, providing with fast and high-quality wood production, landscape diversity, as well as lucrative materials for medicinal and industrial use. Its natural range of distribution is in the northern part of Canada and the Pacific coast, up to 3,000 $\mathrm{m}$ a. $\mathrm{s}$. 1 . on Rocky Mts. Its wide geographical range in terms of latitude and longitude (from New Mexico to Vancouver), as well as altitude, has produced a number of provenances.

The successful introduction of Douglas-fir depends on the selection of the most suitable provenances. In Serbia, two provenance trial plantations of the species has been established in order to test its adaptability to the climatic and environmental conditions of new habitats.

In this paper, the analysis of variability of resin canal diameter in the needles of different Douglas-fir provenances was conducted on two sites in Serbia. It was determined that there are significant differences between the mean values of resin canal diameters of some provenances and that the influence of the interaction of "site" and "provenance" factors on the mean values was also significant. Resin has a protective role in conifers.

The results of the present study will contribute to better selection of suitable provenances for the introduction of Douglas-fir in Serba.

\section{VARIJABILNOST PREČNIKA SMOLNIH KANALA U ČETINAMA RAZLIČITIH PROVENIJENCIJA DUGLAZIJE}

Vera LAVADINOVIĆ, Dragica OBRATOV-PETKOVIĆ, Ljubinko RAKONJAC, Zoran MILETIĆ, Filip JOVANOVIĆ, Milan KABILJO

\section{Rezime}

Duglazija [Pseudotsuga menziesii (Mirb.) Franco, fam. Pinaceae] je zastupljena u svim ekosistemima Evrope, obezbeđujući kvalitetan i brz prirast drvne mase, pejzažnu raznolikost, kao i unosan materijal za medicinsku i hemijsku industriju. Prirodno je rasprostranjena u severnom delu Kanade i priobalnom delu Pacifika, sve do $3000 \mathrm{~m}$ nadmorske visine Stenovitih planina. Ovako širok vertikalni i horizontalni areal (od Novog Meksika do Vankuvera) raspolaže velikim brojem provenijencija.

Za introdukciju duglazije potreban je pravilan izbor provenijencije. U Srbiji su postavljeni provenijenični ogledi s ciljem testiranja adaptivnosti ove vrste na klimatske i stanišne uslove novih lokaliteta. 
U radu su izvedena istraživanja prečnika smolnih kanala u četinama duglazije različitih provenijencija na dva lokaliteta u Srbiji. Konstatovano je da postoje razlike u srednjim vrednostima prečnika smolnih kanala kod pojedinih provenijencija, kao i to da kod pojedinih provenijencija interakcija između faktora „lokalitet” i ,provenijencija” utiče na srednju vrednost prečnika smolnih kanala. Uloga smole u četinarima je zaštitna.

Ovim istraživanjem će se doprineti većoj pouzdanosti pri izboru odgovarajućih provenijencija u programu introdukcije duglazije u Srbiji. 